\title{
SCHOOL CONDUCT AND ACHIEVEMENT AS PREDICTORS OF BEHAVIOUR DISORDERS WITH ELEMENTARY SCHOOL CHILDREN
}

\author{
Mirjana Radetić-Paić, PhD \\ Department of educational sciencies \\ University Juraj Dobrila in Pula (Croatia) \\ e-mail: mradeticpaic@hotmail.com \\ Iva Blažević, PhD \\ Elementary School Vidikovac in Pula (Croatia) \\ e-mail: idobrila@yahoo.com \\ Prof. Vesna Babić, PhD \\ Faculty of Kinesiology, \\ University of Zagreb (Croatia) \\ e-mail: vesna.babic@kif.hr
}

\section{$S u m m a r y$}

The aim of this research is to find the connection between school conduct and achievement and behaviour disorders with elementary school children $(\mathrm{N}=242)$ and to establish its predictive values. The research's aim is linked to planning of adequate interventions for elementary school children at risk or with already evident behaviour disorders based on the obtained indicators.

The results have shown that there is a connection between school conduct and smoking as a problematic form of behaviour, while the connection between school achievement and behaviour disorders has not been shown as statistically significant.

The applicative value of the obtained results is shown through the identification of guidelines for preventive interventions on the level of the local community. It is also shown through guidelines for the production and implementation of different programmes in the area of school education and spending free time (sports activities).

Key words: school conduct, school achievement, behaviour disorders, pupils, school, free time, sport, Pula 


\section{Introduction}

Behaviour disorders are different occurrences and forms of a child's reactions which, according to a specific environment, are not in line with the demands and expectancies in relation to age, situation and environment. Children's behaviour disorders can represent a wide spectrum of behaviours, from relatively insignificant behaviours (shouting, swearing, anger) to more sever or serious ones (robbery, violent behaviour, use of addictive substances). When behaviour disorders are under discussion, adaptation or lack of adaptation to the environment demands are in question. That is why the evaluation of behaviour disorders, among others, depends on the so called social criteria (cultural, moral, economic or social development) and also on subjective attitudes of the social environment, especially parents and educators.

When talking about school environment, some children are not able to fulfill the school's expectations. On one hand, school identifies and intensifies the already existing behaviour disorders with pupils bearing development disorders and having unfavourable psychosocial life conditions. On the other hand, it sometimes triggers new behaviour disorders, the source of which is in the school itself. This usually leads to alienation from school or to nonrealisation of school duties, truancy or running away from school. Truancy and running away from school are symptoms of a negative forecast of a pupil's further development. They represent factors of risk for the occurrence and further development of behaviour disorders. It has been noticed that the intensity of lack of adaptation in schools grows with the seriousness of behaviour disorders.

Some twenty years ago, special attention has started to be given to factors of risk for the occurrence and development of behaviour disorders. Knowledge about them has been used in various conceptual frames of prevention and treatment of children's behaviour disorders. The recognition of factors of risk and of needs which contribute or favour the development of children's behaviour disorders are sources for planning proper interventions. Such interventions in all aspects of a young person's development and education create an affect, such as respecting his or her rights and needs. Optimal conditions for the development of a young person's potentials are created. The processes of planning and programming preventive and treatment interventions start with the recognition of factors of risk or needs of a concrete local community which has to take the responsibility of an early identification and intervention. The local community is also responsible of applying strategies which will lower the risk of children and the youth's behaviour disorders occurrence.

Along with factors of risk existing in different areas of a young person's performance, research literature mentions factors linked to the school environment which can, with a higher or lower possibility, predict the occurrence of interferences or disorders.

Williams, Ayers and Arthur (1997) mention the research of factors of risk for the development of behaviour disorders in schools. They point out poor school and academic achievement, discipline problems and insufficient attachment to school. 
The questionnaire for determining the level of interventions and conduction of the case - UZORI (the original name of the questionnaire is Youth Level of Service/Case Management Inventory - YLS/CMI, Hoge, Andrews, Leschield, 2002) is the standardised instrument for the evaluation of the level of risk which integrates different sources, information and knowledge about a particular child/young person with behaviour disorders. It makes possible the provision of well-founded estimates and decisions about the levels of monitoring needed or intensity of the treatment. In this context, the importance of interfering behaviours in the classroom or school environment, poor school achievement, problems with coevals and teachers, running away from school, unemployment or the lack of will for finding one is pointed out.

When it comes to more serious forms of behaviour disorders, some authors say that juvenile delinquents also show a higher level of risk in the area of school education, organisation of free time and association with delinquent persons and groups (Willson and Rollestone, 2004; Barnoski, 2004, according to Schwalbe and partners, 2008).

In the analysis of direct and approximate factors with a direct impact on a young person, Hoge $(2009 ; 52)$ mentions, among others, the antisocial attitudes, values and beliefs, dysfunctional behaviours and personality features, poor school achievement and inadequate spending of ones free time.

The authors Bašić and Kranželić Tavra (2004) mention some of the risky behaviours at school, like early problems with adaptation to school, poor academic and school achievement, leaving school and, in the last time, violence in schools and abuse of addictive substances. Poor school achievements which children and young persons' experience can cause different reactions in the form of aggressive attitudes - hatred toward schools, teachers and school subjects; resignation-lower ambitions, passiveness and apathy; becoming uncommunicative-daydreaming or other activities which compensate the lack of success; regression-infantile or other inadequate behaviours for a child's age.

Poor academic achievement and lack of attachment to the school are the main predictors of later behaviour disorders in school environment (Kranželić-Tavra, 2002). Early behaviour disorders at school, especially aggressive behaviour and bad relationship with coevals are also significant predictors.

The Book of Rules about the Ways of observation and evaluation of elementary school pupils (NN, Narodne Novine, no. 92/95) in effect, in article 2, subsections 3 and 8 , defines evaluation and behaviour evaluation as the estimate of the whole pupils' achievement or behaviour in the school environment. It is mentioned that "evaluation is the estimate of all important facts about a pupil's achievements during monitoring, checking and examining him or her, and it is expressed with a grade in conformity with the law" and "a pupils' behaviour is estimated based on their relationship toward themselves, work and other pupils, teachers and school employees and also toward school property and the wider natural environment."

On the other hand, free time activities and sport represent very important educational activities and are a significant factor in children's development. Taking part in sports activities makes possible a larger number of social contacts and contributes to the development of social behaviour. Non-inclusion of children in free time activities is 
a factor of risk for the occurrence and development of behaviour disorders, because it also makes possible more negative influences by coevals and other groups on the child.

In this sense, the research by authors Đonlić, Marušić-Štimac and Smojver-Ažić (2005) tries to define the connection between joining in and success in organized sports activities and different aspects of self image and behaviour disorders. The results have shown that successful sportspersons have a significantly higher self esteem, and have a positive perception of sports and social competence, unlike an unsuccessful sportsperson or non-sportsperson. At the same time, successful sportspersons have significantly less expressed internalised, externalised and total behaviour problems.

In researches of factors of risk on the level of the local community of Pula, it is significant to point out two major projects. The research project "Models of Interventions with the Aim of Prevention of Children, the Youth and Adults' Behaviour Disorders in the Republic of Croatia" realized by the Department for Behaviour Disorders of the Education-Rehabilitation Faculty from the Zagreb University in the period from 1996. - 1999. (Radetić-Paić, 2003), and the research project "Coordinations of Interventions with Children and the Youth's in Risk Needs: Model Production," also realised by the Department for Behaviour Disorders of the EducationRehabilitation Faculty from the Zagreb University, which has been in use since 2007 on samples of children and young persons at risk for behaviour disorders or with already evident behaviour disorders (Radetić-Paić, 2010). In general, all the observed characteristics in the school environment, such as the interfering behaviours in the classroom, interfering behaviours in the school environment, poor school achievement, problems with coevals and teachers, and running away from school have been estimated by one-third of children and young persons, with the notion that some slight oscillations have been evidenced in some characteristics during the years under observation.

When it comes to the organisation of free time, the results have shown that more of half of the examinees has a limited number of organised activities and that they could use their free time in a better way, as well as that these indicators have not changed in the ten years period for children and young people in risk or with already evident behaviour disorders.

\section{Methods}

\section{Aim, purpose and hypothesis of the research}

The aim of this research is to define the connection between school conduct and achievement and behaviour disorders with elementary school children. The other aim is to define their predictive value. The purpose of the research is linked to the planning of adequate interventions for elementary school children at risk or with already evident behaviour disorders based on obtained indicators. The following hypotheses are tested:

$\mathbf{H}_{\mathbf{1}}$ : there is a statistically significant connection between school conduct and behaviour disorders with elementary school children

$\mathbf{H}_{2}$ : there is a statistically significant connection between school achievement and behaviour disorders with elementary school children. 
The hypotheses are based on the assumption that there are statistically significant connections between school education characteristics like school conduct and achievement and behaviour disorders. Namely, in the research done in Pula (RadetićPaić, 2003) poor school achievement has been evident by more than half of the examinees. With more than one-fourth of children and young people (67 percent of them) a mild risk of the occurrence and development of behaviour disorders has been estimated. One-third of children and young people are at risk or with already evident behaviour disorders have shown interfering behaviours in the classroom, in the school environment, poor school achievement, problems with coevals and teachers and running away from school (Radetić-Paić, 2010). In the analysis of differences in characteristics of school education between children and young people with active and passive behaviour disorders (Radetić-Paić, 2009), it has been determined that the group of children and young people with active behaviour disorders showed difficulties in school education in the form of problems in the relationship with teachers, poor school achievement, truancy and unemployment or the lack of will to find one.

\section{Sample of examinees}

The sample of examinees is made of 242 pupils belonging to the fifth, sixth, seventh and eighth grade of the Elementary School Vidikovac in Pula. The examinees are distributed according to grades in the following way:

- 54 fifth grade pupils (22.3 percent)

- 65 sixth grade pupils (26.9 percent)

- 74 seventh grade pupils (30.6 percent)

- 49 eighth grade pupils (20.2 percent)

The sample of examinees is made of 121 male and 121 female pupils.

\section{Sample of variables}

Behaviour disorders have been estimated by pupils on the scale of the Likert type made of five degrees ( 1 - never, 2 - rarely, 3 - sometimes, 4 - often, 5 - very often). They have estimated if, during the last thirty days, they performed actions which can be defined as behaviour disorders (problematic behaviour), or juvenile delinquency (deviant behaviour). Behaviour disorders (problematic behaviour) have been defined based on some constructions which have been shown as important in the past researches for measuring various forms of such behaviours. The scales have been constructed in such a way that fragments from similar scales (Raboteg-Šarić and Brajša-Žganec, 2000), have been used in similar researches (Berndt, 1979; Tyler and Lichenstein, 1997). Two underscales have been formed in the final version, based on factor analysis: the scale of problematic behaviour (six fragments, $\alpha=.81$ ) and the scale of deviant behaviour (three fragments, $\alpha=.76$ ). Three fragments related to the estimates of pupils about the frequency of undertaking sports activities in their free time, smoking and consumption of alcoholic drinks have been added, which, together with the earlier 
mentioned scales, represent a predictive group of fragments. The criteria fragments are made of fragments school conduct and achievement on the semester. behaviour:

The following fragments have been estimated by the scale of problematic

1. performed acts of malevolence on the teacher

2. destroyed school property

3. went around teasing other children

4. beat and pushed others in the classroom

5. mocked others

6. lied or invented things to cause troubles to others

The following fragments have been estimated by the scale of deviant behaviour:

1. stole from other people

2. shoplifted

3. played truant

Performing sports activities has been estimated by the following fragment:

1. in my free time I practice some sport

Experimenting with some addictive substances has been estimated by the following fragments:

1. How often do you smoke cigarettes?

2. How often do you consume alcohol?

\section{Methods of data processing}

The regression analysis as a multivariate method for data processing has been used by which the prognostic value of the group of predictive variables has been established (according to Kovačević, Stančić, Mejovšek, 1998).

\section{Methods of data collection}

The research has been performed during 2010 in the Elementary School Vidikovac in Pula so that pupils filled in the questionnaire by themselves. Other employees of the mentioned school have also made possible the conduction of the research.

\section{Results of the research}

The regression analysis was carried out using a predictive group of fragments from the scale of problematic behaviours and the scale of deviant behaviours, as well as three fragments related to the pupils' estimates about the frequency of performing 
sports activities in their free time, smoking cigars and consumption of alcoholic drinks. The criteria fragments were school conduct and achievement at the end of the semester.

Table 1 shows the basic statistical values of the observed fragments. It can be noticed that the average values of the observed fragments are different with a special departure in a positive sense in fragments grade and sport and fragments beat/pushed, mocked and teased as negative forms of behaviour.

Table 1. Basic statistical values of the observed fragments

\begin{tabular}{|l|c|c|c|c|}
\hline & Mean & Minimum & Maximum & Std.Dev. \\
\hline \hline achievement & 4,05 & 1,00 & 5,00 & 0,81 \\
\hline school conduct & 1,46 & 1,00 & 3,00 & 0,56 \\
\hline sport & 4,01 & 1,00 & 5,00 & 0,96 \\
\hline malevolence & 1,74 & 1,00 & 5,00 & 1,10 \\
\hline destroyed & 1,38 & 1,00 & 5,00 & 0,80 \\
\hline teasing & 2,01 & 1,00 & 5,00 & 1,10 \\
\hline beat/pushed & 2,07 & 1,00 & 5,00 & 1,07 \\
\hline mocked & 2,04 & 1,00 & 5,00 & 1,06 \\
\hline lied & 1,47 & 1,00 & 5,00 & 0,92 \\
\hline steole - people & 1,19 & 1,00 & 5,00 & 0,58 \\
\hline shoplifted & 1,19 & 1,00 & 5,00 & 0,61 \\
\hline played truant & 1,33 & 1,00 & 5,00 & 0,75 \\
\hline smoke & 1,17 & 1,00 & 5,00 & 0,62 \\
\hline alcohol & 1,38 & 1,00 & 5,00 & 0,78 \\
\hline
\end{tabular}

\section{Results of the multiple regression analysis for the school conduct criteria}

The results obtained for the multiple regression analysis (Table 2) show that there is a statistically significant connection between the predictive fragments and the criteria fragment school conduct. Forty-one percent of the common variance has been explained by the predictive group of fragments. In other words, by knowing fragments from the predictive group it is possible to predict the sample's elementary school pupils' school.

The standard regression coefficient is the highest, and at the same time statistically significant for the fragment smoking. Other predictive fragments also take part in the defining of the latent criteria, but are not statistically significant predictors of the criteria fragment. Therefore, the fragment smoking contributes mostly with its projections to the criteria fragment school conduct. Other fragments by themselves do not significantly predict the criteria school conduct. 
Table 2. Coefficients of the multiple regressions from the predictive group of fragments and the criteria of school conduct.

\begin{tabular}{|l|c|}
\hline & Value \\
\hline \hline Multiple R & 0,410 \\
\hline Multiple R2 & 0,168 \\
\hline Adjusted R2 & 0,123 \\
\hline $\mathrm{F}(12,219)$ & 3,694 \\
\hline $\mathrm{p}$ & 0,000 \\
\hline Std.Err. of Estimate & 0,522 \\
\hline
\end{tabular}

Table 3. Multiple regressions analysis for the criteria school conduct

\begin{tabular}{|l|c|c|c|c|c|c|}
\hline & Beta & $\begin{array}{c}\text { Std.Err. } \\
\text { of Beta }\end{array}$ & B & $\begin{array}{c}\text { Std.Err. } \\
\text { of B }\end{array}$ & $\mathrm{t}(219)$ & p-level \\
\hline \hline sport & 0,077 & 0,065 & 0,045 & 0,038 & 1,193 & 0,234 \\
\hline malevolence & 0,150 & 0,087 & 0,076 & 0,044 & 1,727 & 0,086 \\
\hline destroyed & $-0,013$ & 0,091 & $-0,010$ & 0,066 & $-0,144$ & 0,885 \\
\hline teasing & 0,134 & 0,111 & 0,069 & 0,057 & 1,209 & 0,228 \\
\hline beat/pushed & 0,018 & 0,087 & 0,009 & 0,046 & 0,204 & 0,838 \\
\hline mocked & 0,099 & 0,091 & 0,053 & 0,049 & 1,095 & 0,275 \\
\hline lied & $-0,088$ & 0,077 & $-0,054$ & 0,047 & $-1,145$ & 0,253 \\
\hline steole-people & $-0,040$ & 0,078 & $-0,039$ & 0,076 & $-0,514$ & 0,608 \\
\hline shoplifted & $-0,034$ & 0,073 & $-0,031$ & 0,066 & $-0,468$ & 0,640 \\
\hline played truant & 0,060 & 0,085 & 0,044 & 0,063 & 0,709 & 0,479 \\
\hline smoke & 0,195 & 0,080 & 0,173 & 0,071 & 2,421 & 0,016 \\
\hline alcohol & 0,012 & 0,078 & 0,008 & 0,055 & 0,153 & 0,879 \\
\hline
\end{tabular}

\section{Results of the multiple regression analysis for the school achievement criteria}

The results of the multiple regression analysis of the predictive fragments with the criteria school achievement show that there is not a statistically significant connection between the predictive fragments and the criteria fragment mentioned (Table 4). Therefore, it is not possible to predict the sample's elementary school pupils' school achievement by knowing the observed fragments of the predictive group. 
Table 4. Coefficients of the multiple regressions from the predictive group of fragments and the school achievement criteria

\begin{tabular}{|l|c|}
\hline & Value \\
\hline \hline Multiple R & 0,235 \\
\hline Multiple R2 & 0,055 \\
\hline Adjusted R2 & 0,002 \\
\hline $\mathrm{F}(12,211)$ & 1,032 \\
\hline $\mathrm{p}$ & 0,421 \\
\hline Std.Err. of Estimate & 0,812 \\
\hline
\end{tabular}

Table 5. Multiple regressions analysis for the school achievement criteria

\begin{tabular}{|l|c|c|c|c|c|c|}
\hline & Beta & $\begin{array}{c}\text { Std.Err. } \\
\text { of Beta }\end{array}$ & B & $\begin{array}{c}\text { Std.Err. } \\
\text { of B }\end{array}$ & $\mathrm{t}(211)$ & $\mathrm{p}$-level \\
\hline sport & 0,031 & 0,070 & 0,026 & 0,059 & 0,444 & 0,657 \\
\hline malevolence & $-0,216$ & 0,094 & $-0,162$ & 0,071 & $-2,289$ & 0,023 \\
\hline destroyed & 0,033 & 0,101 & 0,034 & 0,105 & 0,323 & 0,747 \\
\hline teasing & 0,065 & 0,122 & 0,049 & 0,091 & 0,537 & 0,592 \\
\hline beat/pushed & 0,049 & 0,100 & 0,037 & 0,075 & 0,489 & 0,625 \\
\hline mocked & 0,007 & 0,100 & 0,005 & 0,077 & 0,068 & 0,946 \\
\hline lied & 0,034 & 0,085 & 0,031 & 0,076 & 0,403 & 0,687 \\
\hline steole - people & 0,018 & 0,085 & 0,025 & 0,116 & 0,215 & 0,830 \\
\hline shoplifted & 0,020 & 0,081 & 0,026 & 0,104 & 0,252 & 0,801 \\
\hline played truant & $-0,127$ & 0,091 & $-0,154$ & 0,110 & $-1,399$ & 0,163 \\
\hline smoke & $-0,011$ & 0,082 & $-0,016$ & 0,127 & $-0,128$ & 0,898 \\
\hline alcohol & $-0,061$ & 0,084 & $-0,066$ & 0,091 & $-0,731$ & 0,466 \\
\hline
\end{tabular}

\section{Conclusion and discussion}

It can be concluded by the indicators obtained by the pupils' from the Elementary School Vidikovac in Pula self estimate that there is a connection between school conduct and smoking as a problematic form of behaviour, while the connection between school achievement and behaviour disorders has not been shown as statistically significant. It is assumed that some desultory factors like the subjective self estimate of the sample pupils or their "defense" mechanisms during filling in the questionnaire affected the statistical lack of connection between school achievement and behaviour disorders. Namely, it is assumed that pupils with poorer school achievement who show behaviour disorders in various areas of their personal functioning and have a worst self image have not shown this image in the questionnaire during their self estimate (consciously or unconsciously).

When it comes to the first hypothesis set, experimenting with smoking does not necessarily mean showing behaviour disorders. It can be a reflexion of the young 
people's need to show themselves more as adults and older. In these ages, young people can show at school some forms of behaviour which need not necessarily represent behaviour disorders, but they can become ones. Along with that, pupils who link positive experiences to school, compared to those who see schools negatively, consume addictive substances more rarely (Maddox and Prinz, 2003).

Therefore, these results corroborate the results of past researches (Bašić and Kranželić-Tavra, 2004; Radetić-Paić, 2010) which lead to the need of a more significant engagement of schools in the prevention of behaviour disorders in the widest sense or engagement of schools in the primary, secondary and tertiary prevention of behaviour disorders.

Attention should be directed to defense factors or to the resilience of children in the school environment, like developing a wide field of social skills, positive interaction with coevals, a high level of sociability and sensitivity, the skills for solving problems and many others.

Concretely, the need is shown for preventive interventions in the form of school programmes which develop social skills. Aimed programmes of early interventions (pupils with poor school achievement, addicts' children, multiproblems families' children, neglected and violented children and aggressive children) are also needed (Radetić-Paić,2010). The afor mentioned preventive programmes on school levels can have a strong impact on positive developmental outcomes with children.

On the other hand, children's free time or sports activities are important areas in which some measures should be established for the prevention of behaviour disorders. In this context, it is necessary to ensure as much quality free time as possible or acting with a plan so that children fulfill their free time with quality activities and programmes which would satisfy their various needs and interests and in that way prevent the occurrence and development of different forms of behaviour disorders.

\section{Bibliography}

1. Berndt, T. J. (1979). Developmental Changes in Conformity to Peers and Parents. Developmental Psychology, 15 (6), 608-616.

2. Bašić, J., Kranželić-Tavra, V. (2004). O ponašanjima učenika i njihovoj pojavnosti u školi. U: Bašić, J., Koller-Trbović N. i Uzelac, S.(ur.), Poremećaji u ponašanju i rizična ponašanja: pristupi i pojmovna određenja, str. 107-119. Zagreb: Edukacijsko-rehabilitacijski fakultet Sveučilišta u Zagrebu.

3. Đonlić, V., Marušić-Štimac, O., Smojver-Ažić, S. (2005). Odgojni aspekti sporta - slika o sebi i problemi ponašanja obzirom na uključenost i uspješnost djece u sportskim aktivnostima. Zbornik radova VI konferencije o športu RZ Alpe - Jadran, Opatija, str.197-204.

4. Hoge, R.D., Andrews, D.A., Leschield, A.W. (2002). Youth Level of Service/Case Management Inventory. Toronto: MHS.

5. Hoge, R.D. (2009). Advances in the Assessment and Treatment of Juvenile Offenders. Kriminologija i socijana integracija, 17 (2), 49-71. 
6. Koller-Trbović, N. (2004). Poremećaji u ponašanju djece i mladih. U: Bašć, J., KollerTrbović. i Uzelac, S. (ur.), Poremećaji u ponašanju i rizična ponašanja: pristupi i pojmovna određenja, str. 83-96. Zagreb: Edukacijsko-rehabilitacijski fakultet Sveučilišta u Zagrebu.

7. Kovačević, V., Stančić, V., Mejovšek M. (1998). Osnove teorije defektologije. Zagreb: Fakultet za defektologiju Sveučilišta u Zagrebu.

8. Kranželić-Tavra, V. (2002). Rizični čimbenici u školskom okruženju kao temelji uspješnije prevencije poremećaja u ponašanju djece i mladih. Hrvatska revija za rehabilitacijska istraživanja, 38 (1), 1-13.

9. Maddox, S.J., Prinz, R.J. (2003). School Bonding in Children and Adolescents: Conceptualization, Assassment, and Associated Variables. Clinical Child and Familiy Psychology Review, 6 (1), 31-49. novine $92 / 95$.

10. Pravilnik o načinu praćenja i ocjenjivanja učenika u osnovnoj školi (1995). Narodne

11. Raboteg-Šarić, Z., Brajša-Žganec, A. (2000). Roditeljski odgojni postupci i problematično ponašanje djece u ranoj adolescenciji. U: Bašić J. i Janković J. (ur.), Rizični i zaštitni čimbenici u razvoju poremećaja u ponašanju djece $i$ mladeži, str.155-170. Zagreb: Povjerenstvo vlade RH za prevenciju poremećaja u ponašanu djece i mladeži i zaštitu djece s poremećajima u ponašanju.

12. Radetić-Paić, M. (2003). Rizici i intervencije za djecu i mladež s poremećajima u ponašanju grada Pule. Hrvatska revija za rehabilitacijska istraživanja, 39 (2), 223-233.

13. Radetić-Paić, M. (2009). Obilježja školovanja djece i mladih s aktivnim i pasivnim poremećajima u ponašanju. Međunarodni znanstveni skup „Deseti dani Mate Demarina“- Škola po mjeir, str. 539-550. Pula: Odjel za obrazovanje učitelja i odgojitelja Sveučilište Jurja Dobrile u Puli.

14. Radetić-Paić, M. (2010). Specifični rizici i potrebe djece i mladeži s poremećajima u ponašanju grada Pule. Kriminologija $i$ socijalna integracija, 18 (1), 13-23.

15. Schwalbe, C.S., Macy, R.J., Day, S.H., Fraser, M.W. (2008). Classifying Offenders, An Application of Latent Class Analysis to Needs Assessment in Juvenile Justice. Youth Violence and Juvenile Justice, 6 (3), 279 -294.

16. Tyler, J., Lichtenstein, C. (1997). Risk, protective, AOD knowledge, attitude, and AOD behavior: Factors associated with characteristics of high-risk youth. Evaluation and Program Planning, 20, 27-45.

17. Williams, J.H., Ayers, D.C., Arthur, W.M. (1997). Risk and Protective Factors in Development of Delinquency and Conduct Disorders. U: Fraser (ur.). Risk and Resilience in Childhood: An Ecological Perspective, pp. 140-170. NASW Press.

18. Wilson, N., Rolleston R. (2004). A Risk - Need Profile Using Four Measures for Yuoth Offenders Incarcerated in Youth Offender Units. New Zeland: Department of Corrections Research. 
Metodički obzori 7(2012)1

Izvorni znanstveni rad

UDK: 371.26:371.5]:373.3

Primljeno: 29. 9. 2010.

\section{VLADANJE I ŠKOLSKO POSTIGNUĆE KAO PREDIKTORI POREMEĆAJA U PONAŠANJU DJECE U OSNOVNOJ ŠKOLI}

dr. sc. Mirjana Radetić-Paić,

Odjel za obrazovanje učitelja i odgojitelja,

Sveučilište Jurja Dobrile u Puli (Croatia)

e-mail: mradeticpaic@ hotmail.com

dr. sc. Iva Blažević,

Osnovna škola Vidikovac u Puli (Croatia)

e-mail: idobrila@yahoo.com

prof. dr. sc. Vesna Babić,

Kineziološki fakultet,

Sveučilište u Zagrebu (Croatia)

e-mail: vesna.babic@kif.hr

$S \boldsymbol{a} \check{z} \boldsymbol{e} t a k$

Ovo istraživanje ima za cilj utvrditi povezanost između vladanja, školskog postignuća i poremećaja u ponašanju djece osnovnoškolske dobi $(\mathrm{N}=242)$ te utvrditi njihovu prediktivnu vrijednost. Svrha istraživanja povezana je s planiranjem adekvatnih intervencija za djecu osnovnoškolske dobi u riziku ili s već evidentnim poremećajima u ponašanju temeljem dobivenih pokazatelja.

Rezultati pokazuju da postoji povezanost vladanja $\mathrm{s}$ pušenjem kao problematičnim oblikom ponašanja, dok se povezanost školskog postignuća s poremećajima u ponašanju nije pokazala statistički značajnom.

Aplikativna vrijednost dobivenih rezultata očituje se kroz identifikaciju smjernica za preventivne intervencije na razini lokalne zajednice, odnosno smjernice za izradu i provedbu različitih programa na području školovanja i provođenja slobodnog vremena (sportskih aktivnosti).

Ključne riječi: vladanje, školsko postignuće, poremećaji u ponašanju, učenici, škola, slobodno vrijeme, sport, Pula 